\title{
Analysis of problems existing in enterprise marketing - a case study of SMEs
}

\author{
Xiaoqing Zhang \\ Guangzhou Panyu Polytechnic, Guangzhou, 511483, China
}

Keywords: SMEs, Enterprise market, Marketing

\begin{abstract}
In the production and operation of small and medium enterprises, marketing is the most important part, which determines the development of enterprises. However, there are still some problems existed in the marketing process of some enterprises; the specific issues include: the marketing concept is relatively backward, unscientific market research, marketing plan unreasonable, marketing is not advanced, the lack of innovative ideas, management mechanism is not perfect, network marketing Mistakes, low degree of specialization and low quality of the staff, these issues for enterprise development to produce a serious impact. Enterprise marketing problem, it is difficult to improve economic efficiency. Therefore, China's small and medium enterprises should analyze marketing problems and take effective measures to solve them, in order to enhance their marketing management, innovative marketing ideas, and lay a solid foundation for enterprises to sustainable development.
\end{abstract}

\section{Introduction}

In recent years, China's reform and opening up has been gradually accelerating, and the country's reform for market economy system is becoming more and more comprehensive, market-type layout has been transformed by the seller to the buyer type, small and medium enterprises also will face greater challenges. With the domestic market economic reforms, the state SMEs marketing aspects of the industry put forward higher requirements, companies should abandon the traditional marketing ideas, innovative marketing strategy, marketing, introduction of advanced technology, improve the quality of staff. SMEs only carry out all aspects of innovation for marketing efforts in order to improve their economic efficiency, to enable enterprises to meet the marketing needs of the market, based on the position.

\section{Summary of SMEs marketing}

\section{Segment marketing}

In the process of modern SMEs marketing, segment marketing plays an important role. Segment marketing is on the market segmentation buying groups, which are divided into need-based and behavior-type, to facilitate enterprises to understand the market framework, market analysis framework, a clear customer demand, and then work out a reasonable marketing objectives. Marketing Segmentation involves three steps, the first is to investigate the market, and the second is to determine the indicators, the third is to develop subdivision plans. After the breakdown of the strict positioning products, the establishment of product marketing system, the core of the marketing system is the customer. In the highly competitive market environment, the breakdown of marketing can improve their competitiveness, sustainable development.

\section{Brand strategy marketing}

In small and medium enterprises of China, the most important thing is to create excellent brand, the only way to make the business occupy a certain position in the market. Enterprises are generally the first to understand the consumer, according to consumer demand and to establish their own brand logo, so that enterprises by the majority of consumers attention and recognition. With the development of the brand, companies will set up a good image in the minds of consumers, at the same 
time, brand strategy, marketing, consumer decision will also shorten the time, indirectly reduce business risk.

\section{Green marketing}

In recent years, consumers' awareness of environmental protection has been gradually increased, enterprise marketing process to fully utilize the green philosophy, and create a green marketing system, this marketing tool not only meet consumer demand, but also socially approved. At present, the domestic economy is slow, unable to fully implement green marketing ideas, some developed countries have begun to use green marketing, consumer advocate green consumption, save resources, reduce costs, in order to accelerate the country's economic level to enhance the speed.

\section{Integration marketing}

SMEs integrated marketing is integrating single means of marketing tools and fuses in together, carefully analyzing the features of market environment, performing effective adjustment of integrated marketing, strengthen the marketing effect. Marketing tools and marketing is different, the role of is also different, the enterprise will be the different marketing method together, can form a comprehensive marketing system, and improve enterprise economic benefits. Enterprises in the process of integrated marketing method to set up a work target, carry out all work with customers as the core, make marketing integration can effectively play their own advantages, improve enterprise economic benefits.

\section{Problems existed in SMEs marketing}

\section{Marketing concept falls behind}

Along with the social development, the environment of small and medium-sized enterprise marketing has been greatly changed; most companies have been introducing modern marketing concept into each department and enterprise economic efficiency has been improved significantly. However, at present, some enterprises are still in the application of traditional marketing concept, there is no active innovation consciousness; lead to enterprise development is severely hampered. At the same time, some companies fail to realize that the importance of the marketing concept, even learning to other enterprise old marketing concept. The enterprise marketing can imagine as a result, not only will appear the phenomenon of a large number of inventory accumulation, there will be increased debt problem, cause enterprises were forced to shut down, for the survival of enterprises.

\section{Ignore internal management}

Some small and medium sized enterprises only attach importance to international marketing management and ignore internal management in the process of marketing development. With the development of market economy, small and medium enterprises make more and more demands, including: enterprises to understand the market, analyze the market, pay attention to consumers, concerned competitors as well as internal management, including internal management is more importantly, companies only do the internal management, in order to enhance the external marketing efforts. Some low-quality enterprise management personnel, unable to take advanced management tools to improve the internal work, so that enterprises can not only enhance their own strength, but also by the threat of external marketing, unable to capture the market.

\section{Unreasonable marketing plan and strategy}

Some small and medium enterprises use work experience to develop marketing plans and fail to establish a professional planning team, which leads to companies' marketing work with strong arbitrariness, lack of relevance. Some enterprises are facing strong competitors, but did not develop a marketing strategy, a lack of accurate positioning, strategy short-sighted; do not realize the importance of development prospects. Part of the set of corporate marketing strategy, marketing objectives are not realistic, feasibility is not strong, these are the reasons hinder the development of SMEs. 


\section{Lack of innovation capability}

Some small and medium enterprises have relatively single operating characteristics, just keep selling hot-sale products, does not establish an own core technology, it could not be better for business products and technological innovation. There are some small and medium enterprises in the smaller their size, tend toward large-scale direction, after the scale increases, but the blind development of diversified companies focus cannot be built on market research, so that enterprises in the market lack of competitive advantage. Another small and medium enterprises do not understand consumer demand, cannot adhere to green marketing, there is a big gap compared with other advanced enterprises.

\section{Imperfect management mechanism}

The process of SMEs marketing includes: marketing analysis, determining market target, determining marketing strategy, developing marketing plan, implementing plan and controlling plan; in the process, there are lots of change factors; the company has only strengthen the marketing process management, in order to achieve business objectives. However, there exist a number of small and medium enterprises in marketing management issues, such as the difficulty to establish marketing workflow etc. In addition, some companies lack professional management, has not been established channels of communication between departments, resulting in a lack of accuracy of the marketing plan, marketing the effectiveness is minimized. There are a lack of a sound marketing management, marketing management did not establish standardized processes, resulting in marketing planning, developing marketing strategies and marketing information management, etc. can not play a role, companies do not have clearly defined rights and responsibilities of staff, marketing staff management system is not established, lack of incentives and training system.

\section{Lack of marketing morality}

Marketing was established based on good faith and morality is the core to develop their economies. However, there are some companies in their own interests, contrary to morality in the marketing process so that some consumers, damage the interests of partners, so as to make the act that endangers society. These unethical phenomena including: the false nature of advertising, consumer fraud, these problems seriously affect consumer rights awareness, people have begun to focus on business ethics lack of marketing problems, strengthen corporate ethics of marketing, has become the focus of the work.

\section{Methods to solve marketing problems}

\section{Establish marketing network}

Modern Internet marketing has become an important carrier of the market economy. As China's economic is developing, companies have begun to establish a sense of marketing and internet marketing can help businesses better promote their products. Therefore, enterprises should abandon traditional marketing concepts, understanding the importance of the Internet for enterprise development, to establish a marketing network based on the following aspects: First, enterprises should be based on consumer demand market segments. Second, companies should develop a marketing objectives, and detailed analysis of the amount based on market characteristics. Finally, companies should have the resources to effectively mobilize itself, the rational allocation of resources in the market. Thus, the link between the various markets will be set up, forming a complete marketing network in the enterprise. ${ }^{[1]}$

\section{Innovation of marketing idea}

Currently, some companies marketing concept is lagging behind in the commodity marketing process, to focus only on sales and profits of goods, there is no clear whether the goods meet the needs of the consumer market, so marketing slow down the speed of goods and reduce economic efficiency of enterprises. Therefore, companies should innovative marketing concepts, market operators as a 
basis for modern marketing strategies. Enterprises should study the market demand, the market demand for larger production of commodities as the core, so that goods can flow in the market marketing. This is a new marketing concept, based on the consumer market as the center and marketing activities, companies must not only adapt to the current marketing ideas, but also active and innovative marketing concepts, and a new marketing concept to guide to other companies, including : knowledge of marketing, green marketing concept ${ }^{[2]}$.

\section{Innovate marketing channels}

In contemporary SMEs, marketing channel plays a vital role, which determines the development of enterprises. However, there are some companies marketing channels for a single, enterprise merchandising links on disadvantaged, single marketing channels will not only reduce the efficiency of the company's sales, but also inhibit the economic development of enterprises, hindering production. Therefore, enterprises should be innovative marketing channels, develop new marketing approach. First, companies should choose a more prosperous city set point of sale. Second, the enterprise network utilization to come in, so that consumers can order goods via the Internet. Finally, companies regularly develop innovative marketing plans, marketing channels to maintain its effectiveness. This can not only expand the scope of sales of goods, but also can improve economic efficiency of enterprises, laying the foundation for sustainable development of enterprises. ${ }^{\text {[3] }}$

\section{Green marketing}

Nowadays, there is a growing emphasis on green consumption, while green environment protection has become the focus of social work content, but some companies still do not realize the importance of green marketing. In the production process, for their own benefit at the waste of resources, sustainable development of the country and the resources not to pay attention to, it was cast aside by society, even if it will not get good quality consumer support, so that SMEs should be green marketing seriously. Long time ago, China began to develop the green market, in this context, companies should have a green marketing concept, green marketing is that enterprises in the production and sales process, green culture, based on the protection of the environment and conserve resources as a key work, meet consumer demand for green, so that enterprises have consumer support and recognition, at the same time, reduce the risk of the occurrence of waste of resources, and promote the country towards sustainable development ${ }^{[4]}$.

\section{Attach importance to staff's professional quality}

In recent years, the market economy is developing rapidly, in small and medium enterprises, the professional quality and level of work of marketing staff and managers occupies an important position, which will directly affect the marketing efficiency and economic benefits. However, some companies' staff have low professionalism, and the marketing personnel cannot increase sales of enterprises so that enterprises develop into a trough. Therefore, small and medium enterprises should attach importance to this issue, in the recruitment marketing staff, marketing staff to inspect to ensure that their professional qualities up to standard. In the course of their work, regularly scheduled training for staff expertise, marketing means marketing staff conduct periodic updates. To regularly scheduled study management knowledge management, requirements management and reasonable concept of marketing management from abroad, improve management, strengthen the sense of responsibility. In this way, companies can effectively improve staff knowledge of literacy in various positions, and ensure the quality of enterprise sales and management level, to lay a good foundation for the sustainable development of enterprises ${ }^{[5]}$.

\section{Technological innovation}

Small and medium-sized enterprises not only need to innovate for marketing idea, but also need to carry out technological innovation, in various stages of enterprise development, properly introduce advanced materials and technology, use new and high technology into the production process, improve the production efficiency, strengthen the quality of the product. Companies to take 
advantage of new technology of product marketing, such as: wechat marketing, weibo marketing, etc., reducing marketing link, reducing freight cost, to make the enterprise economic benefit is improved.

\section{Conclusions}

Under the influence of market economy, small and medium enterprises only constantly innovate for each link in the marketing process, to ensure marketing efficiency of the enterprise, improve service quality and enhance the management level. On the basis of green marketing enterprises to reduce costs, indirectly boost the national economy, contribute to the development of the country.

\section{Acknowledgments}

This paper is 2014 Higher Vocational Education Reform Project of Guangdong Province: "Study on vocational college business profession and government, banks and enterprise jointly cultivate personnel", Project No.: 201401179

\section{References}

[1] Tang Changsheng. Innovative strategy analysis for enterprise marketing. China Business \& Trade, 2014(8):32-33.

[2] Fu Tingting. Major problems existed in SMEs marketing and countermeasure study. Enterprise culture (Middle periodical), 2013(5):51-51.

[3] Dong Cheng. Analysis on brand positioning issue in marketing. Beautiful poem, 2013(26):44-44.

[4] Zheng Beijun. Medicine enterprise marketing issue. Modern Economic Information, 2013(9):104,106.

[5] Liu Song. Marketing analysis and countermeasure study of Yinkou Bank Dalian Branch. Dalian University of Technology, 2014. 